\title{
GIUSEPPE MAZZA ${ }^{\mathrm{a}, *}$ - FRANCESCO BINAZZI ${ }^{\mathrm{a}, *}$ - DANIELE MARRACCINI ${ }^{\mathrm{b}}$ - LUCA BONCOMPAGNI ${ }^{\mathrm{c}}$ - GIUSEPPINO SABBATINI PEVERIERI ${ }^{a}$ - PIO FEDERICO ROVERSI ${ }^{\mathrm{a}}$ - ELISABETTA GARGANI ${ }^{\mathrm{a}}$
}

\section{EVALUATION OF CHRYSOPERLA CARNEA COMPLEX AND COCCINELLID PREDATORS AS BIOCONTROL AGENTS OF RICANIA SPECULUM (WALKER, 1851) (HEMIPTERA RICANIIDAE)}

\author{
${ }^{a}$ CREA - Research Centre for Plant Protection and Certification. Florence, Italy \\ ${ }^{\mathrm{b}}$ Department of Agriculture, Food and Environment, University of Pisa. Pisa, Italy \\ ${ }^{\mathrm{c}}$ Department of Biology, University of Florence. Florence, Italy \\ *These authors equally contributed to this paper \\ Corresponding Author: Giuseppe Mazza, giuseppe.mazza@crea.gov.it
}

Mazza G., Binazzi F., Marraccini D., Boncompagni L., Sabbatini Peverieri G., Roversi P.F., Gargani E. - Evaluation of Chrysoperla carnea complex and coccinellid predators as biocontrol agents of Ricania speculum (Walker, 1851) (Hemiptera Ricaniidae).

Ricania speculum is an alien insect feeding on several host plants belonging to several families, including important vegetables, crops, ornamental plants, wild plants as well as trees. For the first time, recently, Chrysoperla sp. and coccinellid beetles have been observed preying on this species in the field on Citrus sp. and Laurus nobilis plants. The main purposes of this work were to evaluate the possible predation capability of these groups of insects and determine their prey preference in laboratory trials.

In the choice trials, $R$. speculum nymphs were paired in a confined space and exposed for $24 \mathrm{~h}$ to single predators: Ch. carnea complex and to the coccinellids Cryptolaemus montrouzieri, Adalia bipunctata, Coccinella septempunctata, and Propylea quatuordecimpunctata. Specimens of Aphis rumicis, an aphid frequently found on herbaceous plants, were used as a control prey. In the cage trials, a single Ch. carnea complex second-instar larva was placed into a jar containing a tomato plant with ten $R$. speculum nymphs.

In the choice trials, a high mortality percentage of both preys was observed with the Ch. carnea complex, while in those with Coccinellids only high A. rumicis mortality was reported. In the cage trials, $13 \%$ mortality of $R$. speculm was recorded after $24 \mathrm{~h}$ while after $72 \mathrm{~h}$ and $168 \mathrm{~h}$ prey mortalities reached $18 \%$ and $25 \%$, respectively. The results of the study showed that larvae of the Ch. carnea complex could be potential predators of $R$. speculum, while coccinellids do not seem promising predators of this alien species.

KEY WORDS: alien species; biological control; Chrysopidae; Fulgoromorpha; lacewings; natural enemies

\section{INTRODUCTION}

Ricania speculum (Walker, 1851) (Hemiptera: Fulgoromorpha: Ricaniidae), the black planthopper, is an alien species reported for the first time in Europe in 2009 (MAZZA et al., 2014). Distributed in several countries of Southeast Asia (BOURGOIN, 2021), in a relatively short time, the species has spread to several Italian regions such as Liguria, Toscana, Veneto, Piemonte, and Lazio (MAZZA et al., 2014; ROSSI \& LUCCHI, 2015; SILVESTRI, 2017; MAZZA et al., 2018). More recently, in 2019, it was also found in Friuli-Venezia Giulia and Emilia-Romagna (Marraccini D., pers. obs.).

Ricania speculum is a univoltine species, characterized by a wide polyphagia, which allowed a rapid expansion of this species in the invaded countries (e.g. MAZZA et al., 2014; ROSSI \& LUCCHI, 2015; MAZZA et al., 2018). Females insert their eggs into the woody twigs of many host plants, including important vegetables, crops, ornamental plants as well as wild plants and trees, on which nymphs feed and develop. Many host plants, including important crops such as Olea europaea L. and Vitis spp., are reported to be susceptible, even though the potential economic impact of this pest has never been fully evaluated. Damages mainly include sap suction, wounds, and with- ering of young shoots or branches where the eggs are laid (Rossi et al., 2015; MAZZA et al., 2018). So far, R. speculum has not represented an actual problem, but its increasing populations spreading in new areas are raising some concern, not only for its direct damage but also for the indirect ones. In fact, this pest has also been reported to acquire grapevine Flavescence dorée phytoplasma, though it seems unable to transmit it (GALETTO et al., 2019). No management strategies have been developed for this alien species even though green chromotropic traps have proved effective as a monitoring device (MAZZA et al., 2019). No pesticides have been registered to control this insect and only a few natural enemies have been reported for the entire family Ricanidae; for example, ÇETIN \& SEZEN (2016) investigated the bacterial flora of Ricania simulans (Walker, 1851) and tested with efficacy some bacterial isolates against this pest. GÜÇLÜ et al. (2010) studied the pathogenicity of Lecanicillium muscarium against $R$. simulans and discovered that nymphs were more susceptible than adults to this fungus. Regarding $R$. speculum, LAUDONIA et al. (2017) reported the first record of native parasitoids, which emerged from eggs collected in Liguria (Northern Italy). However, despite the high number of collected samples, only a few parasitoids emerged. Thus, no reports concerning the ef- 
ficacy of natural enemies for controlling $R$. speculum are currently available.

In 2018 during monitoring and research activities on $R$. speculum distribution and host plants (MAZZA et al., 2018), the following observations were made in the field for the first time, particularly on Citrus sp. and Laurus nobilis L. plants: green lacewings of the genus Chrysoperla Steinmann, 1964 (Neuroptera: Chrysopidae) on more than one occasion, and adults of the coccinellid Coccinella septempunctata Linnaeus, 1758 (Coleoptera: Coccinellidae), more rarely, attacked and fed on $R$. speculum nymphs. On the contrary, the same predators have never been reported to attack $R$. speculum adults (Marraccini D., pers. obs.).

In most cases, chrysopid larvae are polyphagous predators feeding on several pests of economic importance (SENIOR \& MCEWEN, 2001). A potential obstacle to the successful use of chrysopids in biological control is represented by the taxonomic complexity of the genus Chrysoperla that is currently under revision (TAUBER et al., 2000; HENRY \& WELLS, 2007). Indeed, Chrysoperla carnea (Stephens, 1836) (Neuroptera: Chrysopidae) appears to be a complex of many cryptic, sibling species, the Chrysoperla carnea complex or carnea-group (THIERRY et al., 1992, 1998; HENRY et al., 2001, 2002; MONSERRAT, 2016). They are particularly attracted to eggs and young larvae of Lepidoptera, aphids, spider mites, scales, psyllids, mealybugs, whiteflies, thrips, leafhoppers, and other soft-bodied preys (PRINCIPI \& CANARD, 1984).

Lacewing larvae are highly predacious and cannibalistic, while adults feed mostly on nectar, pollen, and honeydew, even though some of them can be predators (PAPPAS et al., 2011).

The Chrysoperla carnea complex is not only relatively easy to rear and widely used in biological control but are also commercially available for greenhouse and field application (ATLIHAN et al., 2004; CARILLO et al., 2009; HUANG \& ENKEGAARD, 2010). Unfortunately, the taxon referred to 'Chrysoperla carnea' by the industry may include several taxa from different geographic regions. This represents a risk factor such as the introduction of alien species and the ecological and behavioural differences among the species of the complex (HENRY \& WELLS, 2007). Thus, the clear identification of the best taxa suitable for correct biological control programs represents a continuous challenge (HENRY et al., 2002; LOURENÇO et al., 2006).

Immature and adult coccinellid beetles (Coleoptera: Coccinellidae) are also common and voracious predators feeding mainly on aphids or specific preys (MICHAUD, 2012). DIXON (2000) emphasized three attributes, which make members of the Coccinellidae family successful biological control agents: specificity, voracity, and a high rate of population increase. Coccinellids exhibit, in most cases, a narrow range of prey specificity, however, dominant species tend to be generalists. In fact, it is known that, after a consistent population increase due to aphid outbreaks, some of them are able to switch to alternative prey species contributing to the biological control of pests, which serve only as supplementary food (Michaud, 2012).

Thus, the aims of the present work are to evaluate the potential role of $\mathrm{Ch}$. carnea complex larvae and coccinellid adult beetles as predators of $R$. speculum nymphs, to verify their prey preference in choice trials and to evaluate the amount of prey that predators are able to kill in cage trials.

\section{MATERIALS AND METHODS}

Ricania speculum nymphs (first-third instars according to WILSON et al., 2016) were collected in May-July 2018 and 2019 in Tuscany (Central Italy). A field survey was conducted in suburban areas in the municipality of Viareggio, province of Lucca $\left(43^{\circ} 50^{\prime} 40^{\prime}{ }^{\prime} \mathrm{N} ; 1^{\circ} 16^{\prime} 15^{\prime}\right.$ ' E) in order to collect the species frequently observed here (MAZZA et al., 2018; 2019).

In the same period, adult winged morphs of Aphys rumicis Linnaeus, 1758 and adults of Co. septempunctata were respectively collected on Rumex sp. and Spartium junceum L., during insect collection in countryside areas located close to Florence (4343' $54^{\prime \prime}$ N; $\left.11^{\circ} 15^{\prime} 16^{\prime \prime} \mathrm{E}\right)$.

The adult coccinellids Cryptolaemus montrouzieri Mulsant, 1853, Adalia bipunctata (Linnaeus, 1758), and Propylea quatuordecimpunctata (Linnaeus, 1758) (Coleoptera: Coccinellidae) as well as eggs and larvae of the Ch. carnea complex $\left(\right.$ CrisoPAK $\left.^{\circledR}\right)$ were obtained from BIOPLANET ${ }^{\odot}$ (Cesena, Italy). The bio-factories do not provide a taxonomic certification of the biocontrol agents and thus, specimens belonging to sibling species of the Ch. carnea complex, as previously explained into the introduction, could be potentially present within the same package.

In the laboratory, first instar larvae of Ch. carnea complex were kept in Petri dishes (9 $\mathrm{cm}$ diameter) and daily fed ad libitum with Ap. rumicis to obtain second and third instar larvae suitable for the tests. All stages of the $C h$. carnea complex larvae were identified according to PANTALEONI (1983). Each single larva was kept individually in a Petri dish to avoid cannibalism.

Colonies of all the predator species (larvae of the $C h$. carnea complex and adults of coccinellids) were maintained in Petri dishes ( $9 \mathrm{~cm}$ diameter) and they were daily provided with Ap. rumicis as food ad libitum, during the brief pre-conditioning step up and until the start of the tests.

Similarly, $R$. speculum colonies (nymphs) were reared in the same Petri dishes described above and fed with $L$. nobilis leaves until the beginning of the experiment; the leaves were replenished every two days.

All the insects were reared and maintained in a climatic chamber at $+26{ }^{\circ} \mathrm{C} \pm 1.75$, RH $65 \pm 5 \%$, and 16:8 L:D (HPP750, Memmert GmbH + Co. KG, Schwabach, Germany) and they were all starved for $24 \mathrm{~h}$ before the beginning of the trial according to HUANG \& ENKEGAARD (2010). Individuals were separately placed into glass tubes ( $15 \mathrm{~cm}$ long and $2 \mathrm{~cm}$ diameter) closed at both ends by a $250-\mu \mathrm{m}$-mesh plastic net. The tubes with the speci- 


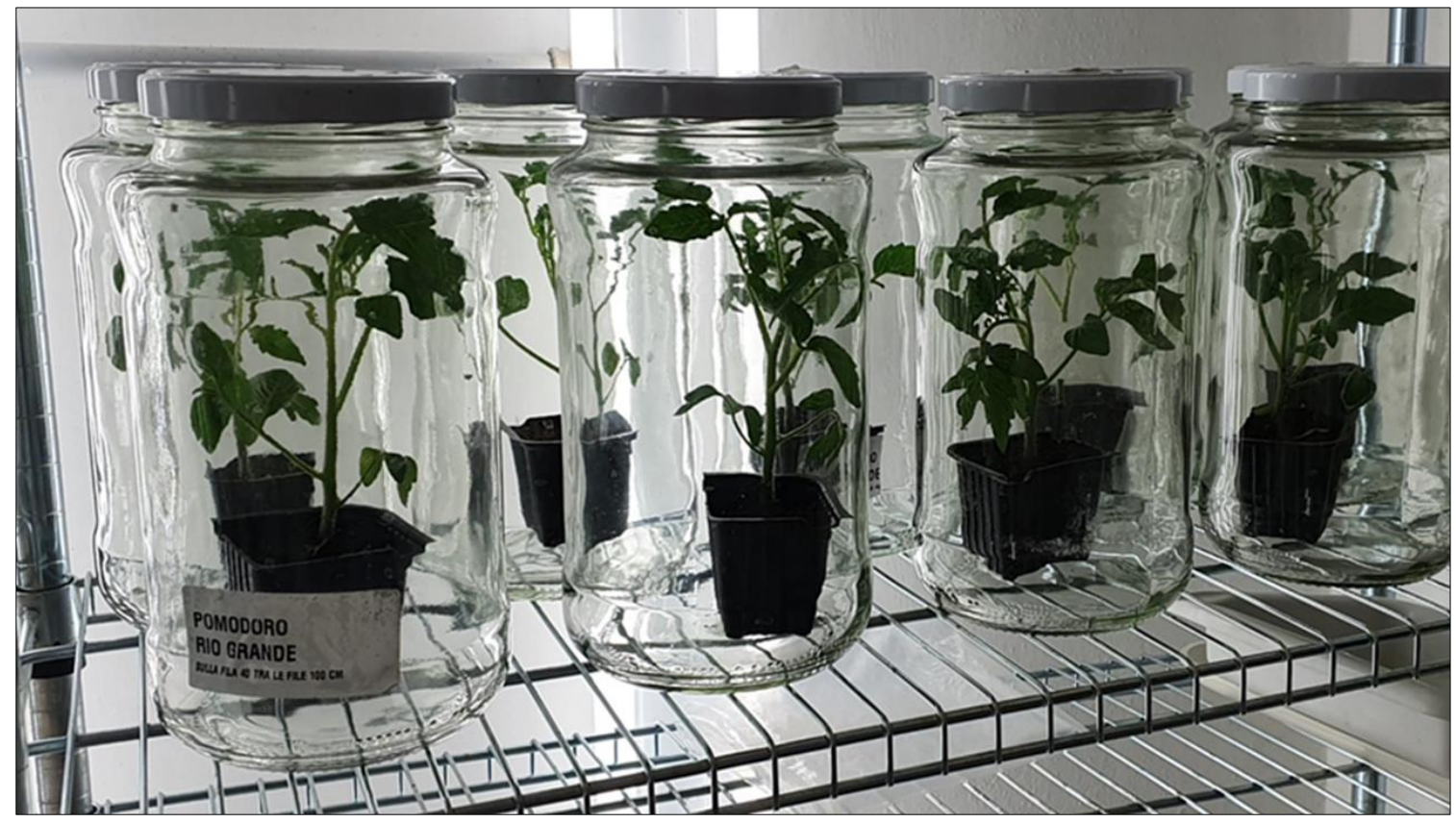

Fig. I - Cage trials: Potted plants of tomato Lycopersicon esculentum Mill. cv. Rio with Ricania speculum nymphs and a second-instar larva of Chrysoperla carnea complex.

mens were then maintained in a climatic chamber at the same conditions described above.

\section{CHOICE TRIALS}

All the experiments were performed in Petri dishes (9 $\mathrm{cm}$ diameter) lined with moistened filter paper and a $L$. nobilis leaf. One single Ap. rumicis (used as positive control) and one $R$. speculum were placed with a fine brush at the opposite extremes of the leaf. Five minutes after the release of the two preys, a single predator from the colonies (Ch. carnea complex, $n=23$ first instar larvae, $n=23$ second instar larvae, $n=23$ third instar larvae; $C r$. montrouzieri, $n=25$; Ad. bipunctata, $n=23$; Co. septempunctata, $n=17 ;$ P. quatuordecimpunctata, $n=18$ ) was placed at the center of the leaf in each dish. Insects were maintained in climatic chambers as described above and after $24 \mathrm{~h}$, prey choice (i.e. predated insects) was assessed under a stereomicroscope following HUANG \& ENKEGAARD (2010).

\section{CAGE TRIALS}

Potted tomato plants (Lycopersicon esculentum Mill. cv. Rio Grande of $10 \mathrm{~cm}$ height) bought from nursery, were placed into glass jars of $25 \mathrm{~cm}$ height and $15 \mathrm{~cm}$ diameter closed by a $250-\mu \mathrm{m}$ mesh plastic net (Fig. I). Plants were grown in a greenhouse under natural light and temperature conditions after being covered during their development with a fine mesh netting as protection from undesired attacks of other insects. Ten $R$. speculum nymphs were inserted into each jar $(n=10)$ containing a potted tomato plant. Two hours after the release of $R$. speculum nymphs, a single second-instar larva of the $C h$. carnea complex was released into each jar. The secondinstar larvae of this predator were selected for further cage trials as they had recorded the maximum peak of predation ( $83 \%$; see below the results section) and were relatively easy to handle in laboratory conditions. This time interval ensured that preys had dispersed throughout the plant. The number of consumed preys was counted after $24 \mathrm{~h}, 72 \mathrm{~h}$, and $168 \mathrm{~h}$ for each of the 10 jars. All the jars were maintained at $25 \pm 2{ }^{\circ} \mathrm{C}$ and $60 \pm 5 \% \mathrm{RH}$ in a controlled rearing room. The peculiar experimental conditions designed in the cage trials were aimed at investigating the searching ability and prey consumption rates of Ch. carnea complex second-instar larvae.

\section{STATISTICAL ANALYSIS}

In the choice trials, an exact McNemar's test was performed to compare mortalities of paired Ap. rumicis and $R$. speculum exposed to each of the investigated predators. A Chi-square test was carried out to compare $R$. speculum mortalities recorded in the three trials involving exposure to different $C h$. carnea development stages (MACDONALD \& GARDNER, 2000; MCDONALD, 2014; ZAR, 2010).

In the cage trials, mortalities of $R$. speculum exposed to second-instar $C h$. carnea complex for various time intervals, were expressed as the number of consumed preys over the total number of preys and calculated after $24 \mathrm{~h}$, $72 \mathrm{~h}$, and $168 \mathrm{~h}$ for each of the 10 jars. Death rates at different time intervals were then compared by the non-parametric Friedman test, as data were not normally distributed and failed transformations. Pairwise comparisons were performed as Post hoc analysis using Wilcoxon signed-rank tests with Bonferroni correction (ZAR, 2010). Statistical analysis was carried out by the software SPSS 20.0 . 


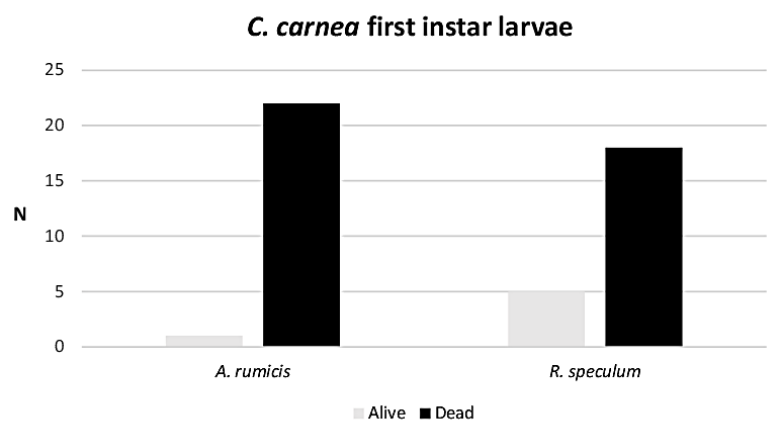

C. carnea second instar larvae

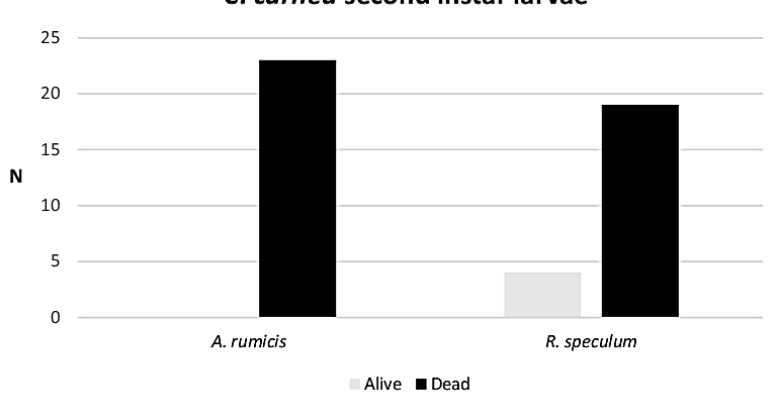

C. carnea third instar larvae

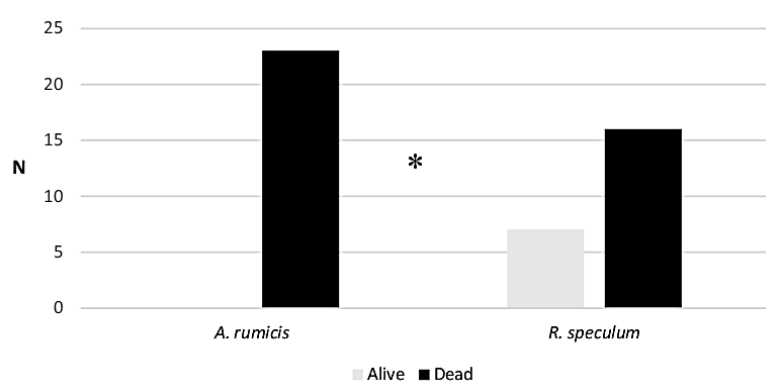

Fig. II - Prey preferences of Chrysoperla carnea complex first-third instar larvae ( $n=23$ for each larval instar) on Aphis rumicis adults and Ricania speculum nymphs in laboratory choice tests. Asterisks indicate significant differences in the number of consumed preys $(* P<0.05$; ** $P<0.01 ; * * * P<0.001)$.

\section{RESULTS}

\section{CHOICE TRIALS}

In the first set of choice tests involving either $A p$. rumicis adults or $R$. speculum nymphs exposed to the predator Ch. carnea complex, high mortality percentages of both species were observed (Fig. II). Specifically, in the first trial with the first instar larvae of $C$. carnea complex, $96 \%$ and $78 \%$ mortality of Ap. rumicis and $R$. speculum were respectively recorded, without a significant difference between the mortalities of the two species $(P$ $=0.125$ ). A similar result was obtained with the second instar larvae of Ch. carnea complex that caused high mortality of both Ap. rumicis and R. speculum (100\% and
$83 \%$ respectively; $\mathrm{P}=0.125$ ). Only in the third trial a significant difference between the mortalities of the two species was observed (100\% for Ap. rumicis and $70 \%$ for R. speculum; $P=0.016)$.
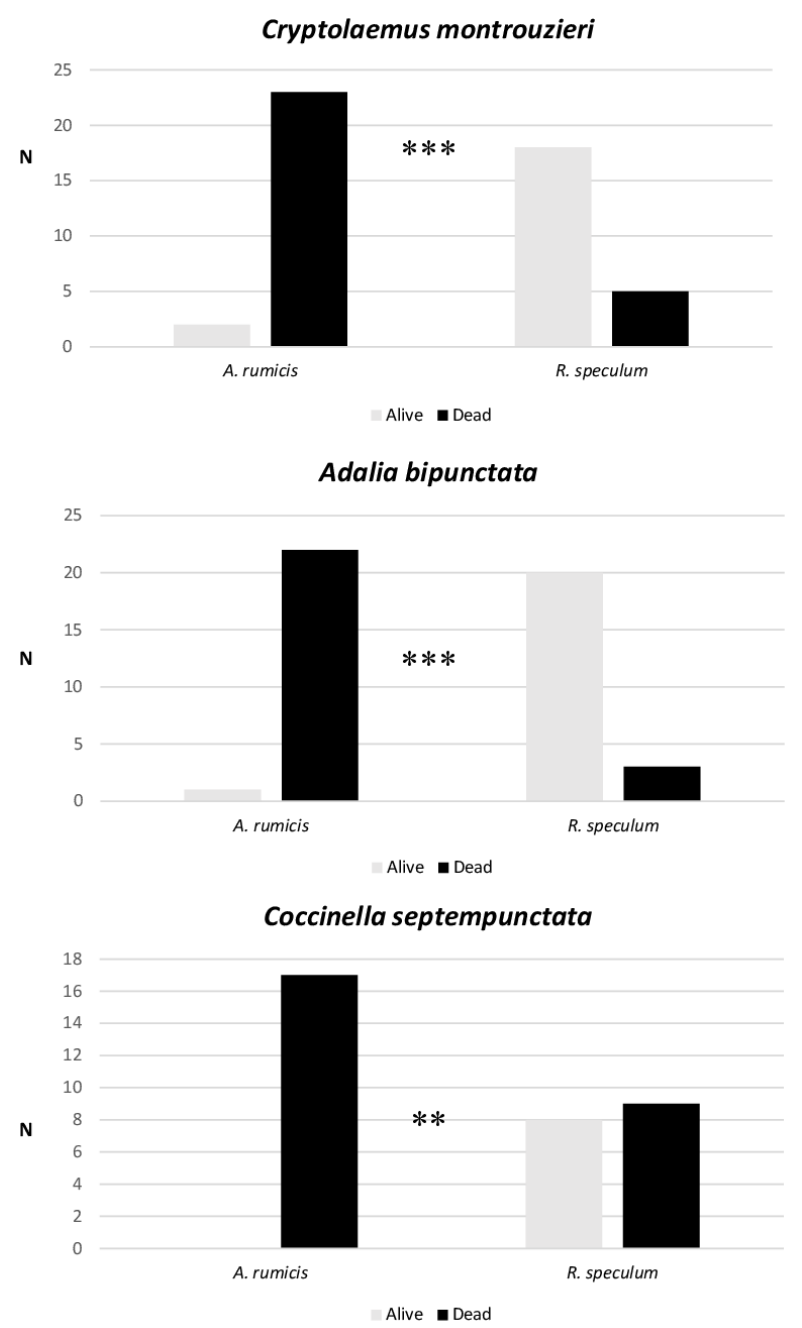

Propylea quatuordecimpunctata

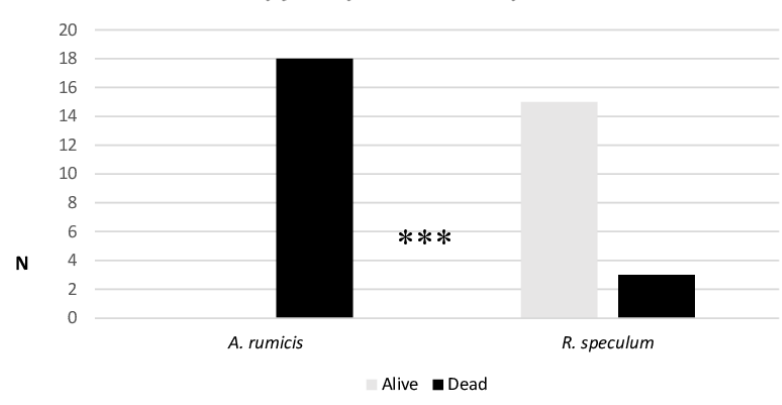

Fig. III - Prey preferences of four Coccinellid adult predators (Cryptolaemus montrouzieri, $n=25$; Adalia bipunctata, $n=23$; Coccinella septempunctata, $n=17$; Propylea quatuordecimpunctata, $n=18$ ) on Aphis rumicis adults and Ricania speculum nymphs in laboratory choice tests. Asterisks indicate significant differences in the number of consumed preys $(* P<0.05$; ** $P<$ $0.01 ; * * * P<0.001)$. 


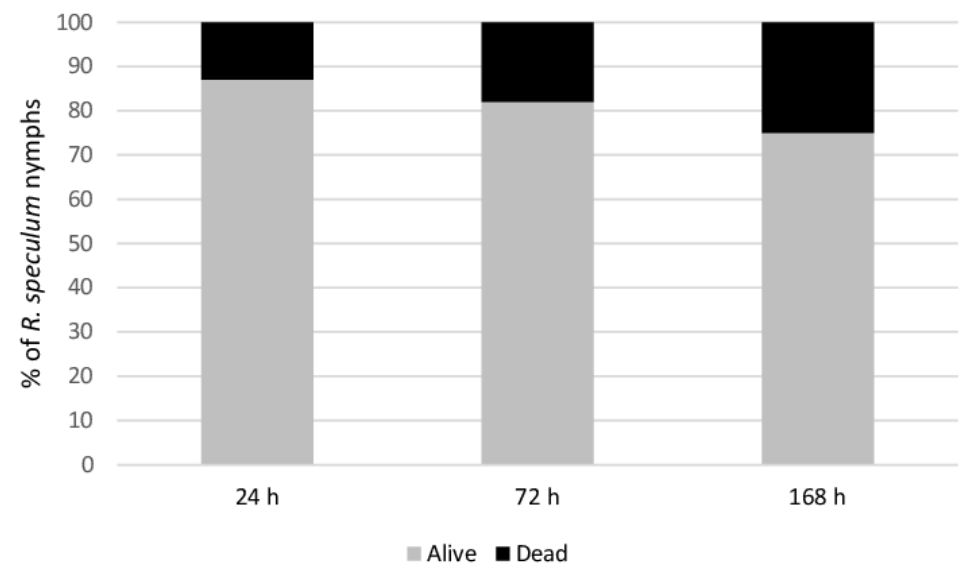

Fig. IV - The percentage of Ricania speculum nymphs $(n=100)$ preyed upon by Chrysoperla carnea complex secondinstar larvae $(n=10)$ after $24 \mathrm{~h}, 72 \mathrm{~h}$, and $168 \mathrm{~h}$ in the cage trials.

Ricania speculum mortality percentages, recorded in the three $C$. carnea trials, were quite similar and always high, ranging from $70 \%$ to $83 \%$. The Chi-Square test detected no significant differences in the proportions of dead specimens $\left(\chi^{2}=1.139 ; \mathrm{df}=2 ; \mathrm{n}=69 ; P=0.566\right)$.

In the second set of choice-tests involving coccinellid predators released against Ap. rumicis and $R$. speculum, high aphid mortalities were observed (Fig. III). When adults of the predator $C r$. montrouzieri were tested against the two preys, $92 \%$ mortality of Ap. rumicis was recorded while only $20 \%$ mortality $R$. speculum was observed $(P=0.00004)$. Similarly, the adults of Ad. bipunctata caused $96 \%$ mortality of Ap. rumicis and only $13 \%$ mortality of $R$. speculum $(P=0.00004)$. When Co. septempunctata was tested, full mortality rate was recorded for Ap. rumicis but not for R. speculum (100\% and 53\% respectively; $P=0.008)$. Also, with the predator $P$. quatuordecimpunctata, $100 \%$ mortality was recorded for Ap. rumicis while only $17 \%$ mortality was observed for $R$. speculum $(P=0.00006)$.

\section{CAGE TRIALS}

In the cage trials, significant differences were recorded in the mortality of $R$. speculum preyed upon by the second-instar larvae of the Ch. carnea complex after $24 \mathrm{~h}$, $72 \mathrm{~h}$, and $168 \mathrm{~h}\left(\chi^{2}=11.00 ; \mathrm{df}=2 ; n=10 ; P=0.004\right)$. After $24 \mathrm{~h}, 13 \% R$. speculm mortality was recorded, whereas after $72 \mathrm{~h}$ and $168 \mathrm{~h}, 18 \%$ and $25 \%$ mortalities were observed, respectively (Fig. IV). Despite a 5\% increase in mortality, no significant difference was observed from $24 \mathrm{~h}$ to $72 \mathrm{~h}(Z=-1.890 ; P=0.059)$, and between $72 \mathrm{~h}$ to $168 \mathrm{~h}$, with a $7 \%$ increase in mortality $(Z=$ -1.841, $P=0.066$ ). However, an overall significant increase in mortality was observed from $24 \mathrm{~h}$ to $168 \mathrm{~h}(Z=$ $-2.414, P=0.015$

\section{DISCUSSION AND CONCLUSIONS}

The results of our study showed that in laboratory choice trials, the Chrysoperla carnea complex preyed upon Ricania speculum nymphs, with quite similar and very high mortality percentages. These values ranged between $70 \%$ to $83 \%$, depending on the development stage of predator larvae. Several species of green lacewings have been reported to preferentially feed on aphids (e.g. CANARD, 2001), with a consumption of up to 160 aphids per day reported in ATLIHAN et al. (2004). Our results not only confirmed the voracious nature of the green common lacewing and its generalist behaviour, but also evidenced, for the first time, its ability to prey on $R$. speculum. In these trials, the Ch. carnea complex larvae were maintained on Aphys rumicis as rearing pabulum. This rearing period was, nonetheless, extremely brief and did not affect the predation ability of the chrysopid larvae, which were equally attracted to the two different preys, as highlighted by the results.

These results are noteworthy because $R$. speculum nymphs are more difficult to predate when compared to aphids. In fact, the antipredator strategies of $R$. speculum nymphs may comprise dodging around to the opposite side of a leaf or branch as well as jumping when a predator approaches it (DIETRICH, 2009). Moreover, Ricania nymphs have not only their body covered by enormous quantities of wax secretions but are also provided with a sort of flexible "wax tail", which can be moved in a parasol-like fashion when nymphs are disturbed (HAMILTON, 2011; WILSON et al., 2016). Thus, this wax can prevent parasites and predators from grasping the nymphs, allowing them to leap away in case of danger (DIETRICH, 2009). However, Chrysoperla carnea complex larvae may overcome such $R$. speculum defense strategies, as observed by our results.

In our trials, only third-instar larvae of the Ch. carnea complex were found to prefer Ap. rumicis, but no significant differences were detected. Moreover, no significant differences were observed in the efficacy of three tested $C$. carnea development stages. Nonetheless, second-instar larvae of this predator were selected for further cage trials as reported above.

In the cage trials, single larvae showed interesting results with $13 \%, 18 \%$, and $25 \%$ mortality of $R$. speculum nymphs at the three tested time intervals. Notwithstanding the relatively low percentages, this experiment on 
prey consumption is promising since single larvae of $C h$. carnea complex and their preys were not confined to small Petri dishes but in a more complex experimental set-up involving potted tomato plants. Further semifield/field trials should be performed using different experimental conditions including other host plants and different predator/prey densities. Indeed, as already reported in ATLIHAN et al. (2004), prey density had a considerable effect on consumption rate, development, and fecundity of this predator. In particular, prey consumption of $C h$. carnea complex larvae rose with increasing prey density. In our trial, only a single larva of the Ch. carnea complex was used in each jar, while hundreds of these predators could be potentially released in the field. Interestingly, even though predators are known to respond to plant volatiles (SHARMA et al., 2019), REDDY (2002) found that when using the olfactometer, Ch. carnea adults did not respond to odors emanating from tomato plants. However, the latter author used the non-predatory $C h$. carnea adults and thus no comparisons can be made with our experiment. Further trials involving $C h$. carnea complex larvae could be performed with other plant hosts since $R$. speculum showed a wide polyphagia (MAZZA et al., 2018).

All the experiments performed with the four different species of coccinellid predators, clearly showed that these beetles preferentially preyed on aphids. It is worth noting that no promising results were obtained with adults, even though they theoretically should be the most suitable life stage for field release, as they are more voracious than larvae. Our results indicate that probably they are not effective biological control agents against $R$. speculum. A higher mortality rate of preys $(53 \%)$ was only recorded in laboratory tests with Co. septempunctata (the coccinellid beetle observed in the field during the predation events on $R$. speculum), but a strong preference for aphids was evident since this species is quite specialist. According to MICHAUD (2012), coccinellids are characterized by prey specificity and most of them are aphidophagous or coccidophagous.

In conclusion, continuous field observations (Marraccini D., pers. obs.) followed by laboratory trials, evidenced that the Ch. carnea complex could be more effective than coccinellid beetles as potential biocontrol agents of $R$. speculum. Nonetheless, additional aspects related to control efficiency require further evaluation in semi-field and field conditions. The accurate identification and use of the cryptic species of the Ch. carnea group could influence the effectiveness of this control agent leading to a more adequate control of this pest being mindful of ethical environmental stewardship, as highlighted by HENRY \& WELLS (2007). Moreover, as already highlighted, the $C h$. carnea complex is still not taxonomically resolved and thus the results could be affected since the tests could be performed with multiple species with different ecology.

Due to the aforementioned problems, the use of $C h$. carnea complex as biocontrol agents must be evaluated with critical attention. Neither the composition nor the origin of the individuals used for massive breeding and sold in these commercial packages are known, thus posing a potential threat to the natural ecosystems.

\section{ACKNOWLEDGEMENTS}

The authors are grateful to Kathleen Collins Tostanoski for the English revision of the manuscript.

We thank Roberto A. Pantaleoni for the identification of the Chrysoperla specimens in the field. We thank Marco Mosti (Bioplanet; Cesena, Italy) for providing the predators used in the experiments. Thanks for the critical revisions provided by the colleagues of the seminar series "Ethology, Ecology, and Evolution: Zoology meetings at the time of Coronavirus disease COVID-19". The research was supported by the Mipaaf Project "SALVAOLIVI, (DD 2017 December 21, n. 33437)" and in the context of the Euphresco Project "International Plant Sentinel Network (IPSN)". Two anonymous reviewers kindly took the time to provide us with useful comments which improved significantly our manuscript.

\section{REFERENCES}

ATLIHAN R., KAYDAN B., ÖZGÖKÇE M.S., 2004 - Feeding activity and life history characteristics of the generalist predator, Chrysoperla carnea (Neuroptera: Chrysopidae) at different prey densities. - Journal of Pest Science, 77(1): 17-21.

BouRGOIN T., 2021. FLOW (Fulgoromorpha Lists on The Web): a world knowledge base dedicated to Fulgoromorpha. Version 8, updated 11.06.2021. http://www.hemiptera-databases.org/flow/

CANARD M., 2001 - Natural food and feeding habits of lacewings. In: McEwen P.K., New T.R., Whittington A. (eds) Lacewings in the Crop Environment- Cambridge University Press: Cambridge, pp. 116-128.

CARILlO M.A., WoOlfolK S.W., HuTChison W.D., 2009 - Green lacewings - http://www.vegedge.umn.edu/vegpest/beneficials/GLW.htm. Consulted on 30 March 2020.

ÇETIN F.A., SEZEN K., 2016 - Discovery and Development of a Biological Agent to Control of Ricania simulans (Hemiptera: Ricaniidae). - JABS, 10(2): 5663.

DIETRICH C.H., 2009 - Auchenorrhyncha: (Cicadas, Spittlebugs, Leafhoppers, Treehoppers, and Planthoppers). Encyclopedia of insects - Academic Press, pp. 56-64.

DIXON A.F.G., 2000 - Insect Predator - Prey Dynamics, Ladybird Beetles and Biological Control - Cambridge University Press: Cambridge, 257 pp.

Galetto L., Pegoraro M., Marzachì C., Rossi E., LuCCHI A., BosCo D., 2019 - Potential role of the alien planthopper Ricania speculum as vector of Flavescence dorée phytoplasma. - European Journal of Plant Pathology, 154(4): 1103-1110.

GÜÇLÜ Ş., AK K., EKEN C., AKYOL H., SEKBAN R., BEYTUT B., YILDIRIM R., 2010 - Pathogenicity of Lecanicillium muscarium against Ricania simulans. - Bulletin of Insectology, 63(2): 243-246.

HAMILTON KGA., 2011 - Making sense of Fulgoroidea 
(Hemiptera): New phylogenetic evidence. - Cicadina, 12: $57-79$.

HenRY C.S., BROOKS S.J., THIERRY D., DuElli P., JOHNSON J.B., 2001 - The common green lacewing (Chrysoperla carnea s. lat.) and the sibling species problem. In: McEwen P.K., New T.R., Whittington A.E. (eds) Lacewings in the crop environment - Cambridge University Press: Cambridge, pp. 29-42.

HenRy C.S., BRoOKS S.J., Duelli P., Johnson J.B., 2002 - Discovering the True Chrysoperla carnea (Insecta: Neuroptera: Chrysopidae) Using Song Analysis, Morphology, and Ecology. - Annals of the Entomological Society of America, 95(2): 172-191.

HENRY C.S., WELLS M.M., 2007 - Can what we don't know about lacewing systematics hurt us? A cautionary tale about mass rearing and release of "Chrysoperla carnea” (Neuroptera: Chrysopidae). - American Entomologist, 53: 42-47.

HUANG N., ENKEGAARD A., 2010 - Predation capacity and prey preference of Chrysoperla carnea on Pieris brassicae. - BioControl 55(3): 379-385.

LAUDONIA S., LUCCHI A., Rossi E., VigGIANI G., 2017 First report on egg-parasitoids of the Asian planthopper Ricania speculum. - Bulletin of Insectology, 70(2): 177-180.

LOUREnÇO P., Brito C., BACKelJaU T., ThIERRY D., VENTURA M.A., 2006 -Molecular systematics of the Chrysoperla carnea group (Neuroptera: Chrysopidae) in Europe. - Journal of Zoological Systematics and Evolutionary Research, 44(2): 180-184.

MCDONALD JH., 2014 - Handbook of biological statistics, 3rd ed. - Sparky House Publishing: Baltimore, MD.

MACDONALD P.L., GARDNER R.C., 2000 - Type I error rate comparisons of post hoc procedures for IXJ chisquare tables. - Educational and Psychological Measurement, 60: 735-754.

MazZa G., PenNaCChio F., GaRgani E., FRANCESCHINI I., ROVERSI P.F., CIANFERONI F., 2014 - First report of Ricania speculum (Walker, 1851) in Europe (Hemiptera: Fulgoromorpha: Ricaniidae). - Zootaxa, 3861: 297-300.

MAZZA G., MARRACCINI D., LUCCHI A., MARIANELli L., SABBAtini PEVERIERI G., Bosio G., GiACOMETTO E., RAPA L., CIANFERONI F., ROVERSI P.F., GARGANI E., 2018 - First record of Ricania speculum (Walker, 1851) (Hemiptera: Ricaniidae) from Veneto, Piedmont and Latium regions and new host plants. - Redia, 101: 197-200. http://dx.doi.org/10.19263/REDIA-101.18.27

Mazza G., Marraccini D., Mori E., Priori S., MARIANELli L., ROVERSI P.F., GARGANI E., 2019 Assessment of color response and activity rhythms of the invasive black planthopper Ricania speculum (Walker, 1851) using sticky traps. - Bulletin of Entomological Research, 1-7. doi:10.1017/S0007485319 00083X

MICHAUD J.P., 2012 - Coccinellids in biological control. Ecology and Behaviour of the Ladybird Beetles (Coccinellidae). - Chichester: John Wiley \& Sons, pp. 488-519.
MONSERRAT V.J., 2016 - Los Crisopidos de la península Ibérica y Baleares (Insecta, Neuropterida, Neuroptera: Chrysopidae). - Graellsia, 72(1):e037. http://dx.doi.org/10.3989/graellsia.2016.v72.143

PANTALEONI R.A., 1983 - Riconoscimento in campo delle larve di crisopidi. - Informatore Fitopatologico, 7(8): 31-36.

PAPPAS M.L., BRoufAS G.D., KoveOS D.S., 2011 Chrysopid predators and their role in biological control. - Journal of Entomology, 8(3): 301-326.

PRINCIPI M.M., CANARD M., 1984 - Feeding habits. In: Canard M., Séméria Y., New T.R. (eds) Biology of Chrysopidae: chapter 4: life histories and behavior. The Hague: Dr W. Junk Publishers, pp. 76-92.

REDDY G.V.P., 2002 - Plant volatiles mediate orientation and plant preference by the predator Chrysoperla carnea Stephens (Neuroptera: Chrysopidae). - Biological Control, 25(1): 49-55.

Rossi E., LUCCHI A., 2015 - The Asian planthopper Ricania speculum (Walker) (Homoptera Ricaniidae) on several crops in Italy: A potential threat to the EPPO region? - Bulletin OEPP / EPPO Bulletin, 45: 1-4.

Rossi E., STROIŃSKI A., LUCCHI A., 2015 - Egg morphology, laying behavior and record of the host plants of Ricania speculum (Walker, 1851), a new alien species for Europe (Hemiptera: Ricaniidae). Zootaxa, 4044: 93-104.

SENIOR L.J., MCEWEN P.K., 2001 - The use of Lacewings in Biological Control. In: McEwen P.K., New T.R., Whittington A.E. (eds) Lacewings in the Crop Environment. - Cambridge: Cambridge University Press, pp: 296-302.

Sharma A., KAUR SANDHI R., REDDY G.V.P., 2019 - A Review of Interactions between Insect Biological Control Agents and semiochemicals. - Insects, 10: 439. doi:10.3390/insects 10120439

SILVESTRI S., 2017 - La Problematica delle specie aliene: il caso di studio di Ricania speculum (Walker, 1851), (Hemiptera, Ricaniidae), insetto esotico di recente introduzione in Europa. - Tesi di Laurea, Università degli Studi di Pisa, 87 pp.

TAUber M.J., TAUber C.A., DAANE K.M., HAGEN K.S., 2000 - Commercialization of predators: Recent lessons from green lacewings (Neuroptera: Chrysopidae). - American Entomologist, 46: 26-37.

THIERRY D., ClOUPEAU R., JARRY M., 1992 - La chrysope commune Chrysoperla carnea (Stephens) sensu lato dans le centre de la France: mise en évidence d'un complexe d'espèces (Insecta: Neuroptera: Chrysopidae). In: Canard M., Aspöck H., Mansell M.W. (eds) Current Research in Neuropterology (Proceedings of the Fourth International Symposium on Neuropterology, Bagnante-de-Luchon, 1991). Toulouse, 379-392.

ThIERRY D., Cloupeau R., JARry M., CANARD M., 1998 - Discrimination of the West-Palaearctic Chrysoperla Steinmann species of the carnea Stephens group by means of claw morphology (Neuroptera, Chrysopidae). - Acta Zoologica Fennica, 209: 255-262.

WILSON S.W., ROSSI E., LUCCHI A., 2016 - Descriptions of the adult genitalia and immatures of the Asian 
planthopper Ricania speculum (Hemiptera: Fulgoroidea: Ricaniidae) recently introduced to Italy. Annals of the Entomological Society of America, 109(6): 899-905.
ZAR J.H., 2010 - Biostatistical analysis, 5th ed. - Englewood Cliffs, NJ: Prentice Hall. 